\title{
Structure-activity relationship study of secondary metabolites from Mesua beccariana, Mesua ferrea and Mesua congestiflora for anti-cholinesterase activity
}

\begin{abstract}
Our search for potential anti-acetylcholinesterase (AChE) inhibitors for treatment of Alzheimer's disease has led to the discovery of two bioactive compounds, $\alpha$-mangostin (11) and congestiflorone acetate (13). This discovery was achieved from a preliminary screening of the anti-AChE activity on the extracts of three Mesua species namely M. ferrea, M. beccariana and M. congestiflora using Ellman's method. The pure metabolites, 1-12 which were isolated from the Mesua species, along with a synthetic derivative, compound $\mathbf{1 3}$ were then evaluated for their activities in order to identify the compounds that correspond to the enzyme inhibitory activities. Compounds $\mathbf{1 1}$ and $\mathbf{1 3}$ were found to give significant anti-AChE activities with $\mathrm{IC}_{50}$ values of 17.51 and $20.25 \mu \mathrm{M}$.
\end{abstract}

Keyword: Anti-acetylcholinesterase; Mesua ferrea; Mesua beccariana; Mesua congestiflora; $\alpha$-mangostin; Congestiflorone acetate 